\title{
Effects of ambient temperature and dietary glycerol addition on growth performance, blood parameters and immune cell populations of Korean cattle steers
}

\author{
Hyeok Joong Kang ${ }^{1}$, Min Yu Piao ${ }^{1}$, In Kyu Lee ${ }^{1}$, Hyun Jin Kim¹, Min Jeong Gu', Cheol-Heui Yun ${ }^{1,2}$, \\ Jagyeom $\mathrm{Seo}^{3}$, and Myunggi Baik ${ }^{1,2, *}$
}

\author{
* Corresponding Author: Myunggi Baik \\ Tel: +82-2-880-4809, Fax: +82-2-873-2271, \\ E-mail: mgbaik@snu.ac.kr \\ 'Department of Agricultural Biotechnology and \\ Research Institute of Agriculture and Life Sciences, \\ College of Agriculture and Life Sciences, Seoul \\ National University, Seoul 08826, Korea \\ ${ }^{2}$ Institute of Green Bio Science and Technology, \\ Pyeongchang 25354, Korea \\ ${ }^{3}$ Life and Industry Convergence Research Institute \\ and Department of Animal Science, College of \\ Natural Resources and Life Science, Pusan National \\ University, Miryang 50463, Korea
}

Submitted Jun 13, 2016; Revised Jul 19, 2016; Accepted Sept 5, 2016
Objective: This study was performed to evaluate whether ambient temperature and dietary glycerol addition affect growth performance, and blood metabolic and immunological parameters, in beef cattle.

Methods: Twenty Korean cattle steers (405.1 $\pm 7.11 \mathrm{~kg}$ of body weight [BW], $14.2 \pm 0.15$ months of age) were divided into a conventional control diet group $(n=10)$ and a $2 \%$ glycerol- added group $(\mathrm{n}=10)$. Steers were fed $1.6 \%$ BW of a concentrate diet and $0.75 \%$ BW of a timothy hay diet for 8 weeks ( 4 weeks from July 28th to August 26th and 4 weeks from August 27th to September 26th). Blood was collected four times on July 28th, August 11th, August 27th, and September 26th.

Results: The maximum indoor ambient temperature-humidity index in August (75.8) was higher $(\mathrm{p}<0.001)$ than that in September $(70.0)$, and in August was within the mild heat stress (HS) category range previously reported for dairy cattle. The average daily gain (ADG; $\mathrm{p}=0.03$ ) and feed efficiency $(\mathrm{p}<0.001)$ were higher in hotter August than in September. Glycerol addition did not affect ADG and feed efficiency. Neither month nor glycerol addition affected blood concentrations of cortisol, triglyceride, or non-esterified fatty acid. Blood concentrations of cholesterol, low-density lipoprotein, high-density lipoprotein, glucose, and albumin were lower $(\mathrm{p}<0.05)$ on August 27th than on September 26 th, and blood phosphorus, calcium and magnesium concentrations were also lower on August 27th than on September 27th. Glycerol addition did not affect these blood parameters. Percentages of $\mathrm{CD}^{+} \mathrm{T}$ cells and $\mathrm{CD} 8^{+} \mathrm{T}$ cells were higher $(\mathrm{p}<0.05)$ on July 28th than on August 27 th and September 26 th. The blood CD ${ }^{+} \mathrm{T}$ cell population was lower in the glycerol supplemented-group compared to the control group on July 28 th and August 27th.

Conclusion: Korean cattle may not be significantly affected by mild HS, considering that growth performance of cattle was better in hotter conditions, although some changes in blood metabolic and mineral parameters were observed.

Keywords: Beef Cattle; Ambient Temperature; Glycerol Addition; Growth; Blood Metabolites; Immune Cells

\section{INTRODUCTION}

The global-mean surface air temperature has increased by $0.6^{\circ} \mathrm{C} \pm 0.2^{\circ} \mathrm{C}$ during the last 100 years [1]. In the Korea peninsula, mean temperature has increased by approximately $2^{\circ} \mathrm{C}$ from 1992 to 2004 [2], showing that the average temperature increase was higher in Korea compared to global surface temperatures. Heat stress (HS), a combination of high temperature and humidity, is a major factor that can negatively affect growth performance, milk production, reproduction, feed intake, overall health, and the well-being of cattle $[3,4]$. The endocrine system, associated 
with heat and energy metabolism, is altered under HS conditions [5]. For example, the levels of glucocorticoids and catecholamines associated with adaptation to HS are increased upon heat exposure [6]. In cattle, catecholamines activate sweat glands [7]. Glucocorticoids may control vasodilation to assist heat loss and produce a stimulatory effect on proteolysis and lipolysis [8]. These hormonal imbalances can affect energy metabolism and allow cattle to utilize more energy for maintaining homeostasis. Therefore, providing additional energy to animals may help offset the reduction of intake [9].

Glycerol has been used as an additional energy source for cattle to enhance growth performance and nutrient digestibility [10]. Glycerol-supplemented cows have been found to have higher concentrations of plasma glucose, and lower concentrations of plasma beta-hydroxybutyrate and urine ketones, suggesting an improvement in net energy availability [11]. Glycerol supplementation in an early lactation dairy cow was shown to increase milk yield with no subsequent decrease in metabolic status [12]. It has been suggested that the addition of dietary glycerol and a direct-fed microbial could improve milk yield in dairy cows subjected to HS [13].

To the best of our knowledge, limited information is available regarding the effects of dietary glycerol addition on animal performance and metabolic parameters in beef cattle during hot weather. We performed this study to examine whether ambient temperature and replacement of portions of corn sources with dietary glycerol in iso-energy levels affect growth, feed efficiency, blood metabolites, and immune cell populations in Korean cattle steers.

\section{MATERIALS AND METHODS}

\section{Animals and feeding trial}

All experimental procedures involving animals were approved by the Seoul National University Institutional Animal Care and Use Committee (SNUIACUC), Republic of Korea, and conducted in accordance with the Animal Experimental Guidelines provided by SNUIACUC.

The study was conducted at the University Animal Farm of the College of Agriculture and Life Sciences, Pyeongchang Campus of Seoul National University, South Korea. Twenty Korean cattle steers with an average age of $14.2 \pm 0.15$ months and weight of $405.1 \pm 7.11 \mathrm{~kg}$ were used. Steers have been fed a commercial growing stage concentrate diet using an automatic feeding station (DeLaval Alpro system, DeLaval, Sweden) and a timothy with conventional feeding program. Water was provided freely. From two weeks before experiment, all animals were fed an experimental control concentrate diet (approximately 1.6\% of body weight $[\mathrm{BW}]$ per animal) and a timothy (approximately $0.75 \%$ of BW per animal). Steers were assigned into one of 2 treatments (control and glycerol concentrate diet group). The glycerol-added diet was made by adding $99.7 \%$ purified glycerol (Palm Oleo
SDN. BHD., Selangor, Malaysia)-adsorbed ground wheat to give final $2.0 \%$ glycerol during pelleting process of a concentrate diet. A portion of corn sources (ground corn, corn flour, corn gluten feed) of control diet were replaced by glycerol to give iso-energy content between control and glycerol diet. The diet formulation and chemical composition of the experimental diets are shown in Table 1. Experimental feeding periods 1 (P1) and 2 (P2) were 4 weeks in duration (July 28th to August 26th and August 27th to September 26th, respectively). During feeding trial, steers were fed a concentrate diet (1.6\% of BW per animal) using an automatic feeding station and a timothy hay (approximately $0.75 \%$ of BW per animal). Daily feed intake of a concentrate diet was recorded automatically online using a computer with the DeLaval Alpro system. Equal amounts of hay were provided twice a day ( 8 am and $6 \mathrm{pm}$ ), and residual hay was weighed before the morning feeding. Samples of concentrate and hay were collected weekly and stored until analysis. BW was measured at 9 am before the feeding at start date and at 4 and 8 weeks after experiment.

\section{Analysis of chemical composition}

The chemical composition (dry matter [DM], crude protein [CP], ether extract [EE], ash, $\mathrm{Ca}$, and $\mathrm{P}$ ) of the concentrate diet and timothy hay was determined using the [14]. The neutral detergent fiber and acid detergent fiber contents were analyzed using the sequential method with the ANKOM200 Fiber Analyzer (Ankom Technology Corp., Macedon, NY, USA) and reagents.

\section{Blood collection and measurement of ambient temperature and rectal temperature}

Blood was collected at 08 to $10 \mathrm{am}$, four times (July 28th, August 11th, August 26th, and September 26th, 2014) after a $9 \mathrm{~h}$ fast. Blood was collected by jugular venipuncture with both a nonheparinized vacutainer $(20 \mathrm{~mL}$; Becton-Dickinson, Franklin Lakes, NJ, USA) and ethylenediaminetetraacetic acid-treated vacutainer $(20 \mathrm{~mL})$. Both serum and plasma were separated by centrifugation at $1,500 \mathrm{~g}$ at $4^{\circ} \mathrm{C}$ for 15 minutes, and stored at $-80^{\circ} \mathrm{C}$ until analysis.

The ambient temperature and relative humidity at the experimental farm were recorded at $1 \mathrm{~h}$ intervals using three $\mathrm{HOBO}$ data loggers (Onset Computer Corp., Cape Cod, MA, USA), and monthly average values of minimum, mean, and maximum temperatures, in combination with humidity, were calculated using daily data. From the automatic recording of the temperature and humidity data, the temperature-humidity index (THI; modified from [15]) was calculated as previously described [16]. A roof covered the experimental farm and both side doors were closed. Therefore, the effects of rain, direct sunlight and wind could be discounted, and both humidity and temperature were major factors in the climatic conditions.

Rectal temperatures were measured at 12:00 $\mathrm{h} 1$ day after blood 
Table 1. Ingredients of the concentrated diet and composition of experimental diets for Korean cattle steers.

\begin{tabular}{|c|c|c|c|c|c|c|}
\hline \multirow{2}{*}{ Ingredients } & \multirow{2}{*}{ Control } & \multirow{2}{*}{ Treatment } & \multirow{2}{*}{ Chemical composition } & \multicolumn{2}{|c|}{ Concentrate diet } & \multirow{2}{*}{ Timothy hay } \\
\hline & & & & Control & Treatment & \\
\hline Concentrate diet & & & Dry matter (DM) & 86.47 & 86.56 & 91.61 \\
\hline Ground corn & 2.16 & 1.35 & Crude protein $(\mathrm{CP})$ & 13.33 & 13.69 & 5.96 \\
\hline Steamed-flaked corn & 21.00 & 21.00 & Ether extract (EE) & 3.43 & 3.39 & 1.63 \\
\hline Ground wheat & 26.54 & $30.20^{1)}$ & Ash & 5.76 & 5.84 & 5.76 \\
\hline Salt & 0.20 & 0.20 & $\mathrm{Ca}$ & 0.92 & 1.03 & 0.27 \\
\hline Molasses & 4.20 & 4.20 & $\mathrm{P}$ & 0.44 & 0.39 & 0.12 \\
\hline Soy hull & 3.00 & 7.00 & Acid detergent fiber (ADF) & 11.9 & 12.4 & 39.98 \\
\hline Corn flour & 9.00 & 5.00 & Neutral detergent fiber (NDF) & 23.9 & 23.8 & 65.90 \\
\hline Rice bran & 3.00 & 1.78 & & & & \\
\hline Cottonseed hulls & 2.00 & 2.00 & & & & \\
\hline Palm kernel meal & 7.00 & 8.00 & & & & \\
\hline Ammonium chloride & 0.15 & 0.15 & & & & \\
\hline Urea & 0.34 & 0.34 & & & & \\
\hline Sodium bicarbonate & 0.75 & 0.75 & & & & \\
\hline Condensed molasses solubles & 1.40 & 1.18 & & & & \\
\hline Corn gluten feed & 10.78 & 3.30 & & & & \\
\hline Limestone & 2.09 & 2.06 & & & & \\
\hline Copra meal & 5.53 & 8.64 & & & & \\
\hline Palm oil & 0.70 & 0.70 & & & & \\
\hline Purified glycerol (99.7\% aqueous solution) & - & 2.00 & & & & \\
\hline Mineral/vitamin $\mathrm{premix}^{2)}$ & 0.17 & 0.17 & & & & \\
\hline Total & 100.00 & 100.00 & & & & \\
\hline \multicolumn{7}{|l|}{ Calculated nutrients } \\
\hline $\operatorname{TDN}^{3)}(\%)$ & 75.61 & 75.53 & & & & \\
\hline $\mathrm{ME}^{4)}(\mathrm{Mcal} / \mathrm{kg})$ & 2.65 & 2.65 & & & & \\
\hline $\mathrm{NEg}{ }^{5)}(\mathrm{Mcal} / \mathrm{kg})$ & 1.24 & 1.24 & & & & \\
\hline
\end{tabular}

TDN, total digestible nutrient; NFC, nonfiber carbohydrate; DE, digestible energy; ME, metabolizable energy; NEg, net energy for gain; NDF, neutral detergent fiber.

1) $2.0 \%$ out of 30.2 was glycerol-adsorbed ground wheat.

${ }^{2)}$ Mineral and vitamin premix contained vit. A 2,650,000 IU, vit. D 530,000 IU, vit. E 1,050 IU, niacin 10,000 mg, Mn 4,400 mg, Zn 4,400 mg, Fe 13,200 mg, Cu 2,200 mg, iodine 440 $\mathrm{mg}$, and Co $440 \mathrm{mg} / \mathrm{kg}$ of Grobic-DC. Grobic-DC was provided by Bayer Health Care (Leverkusen, Germany).

${ }^{3)} \mathrm{TDN}(\%)=\mathrm{NFC}+\mathrm{CP}+[(\mathrm{EE}-1) \times 2.25]+\mathrm{NDF}-7[40] .{ }^{4)} \mathrm{ME}=[1.01 \times(\mathrm{DE})-0.45]+0.0046 \times(\mathrm{EE}-3)[40] .{ }^{5} \mathrm{NEg}=1.42 \mathrm{ME}-0.174 \mathrm{ME}^{2}+0.0122 \mathrm{ME}^{3}-1.65[40]$.

collection using a thermometer (MT200, Microlife, Widnau, Switzerland) with $0.1^{\circ} \mathrm{C}$ accuracy.

\section{Blood analysis}

The blood serum was used for metabolite analysis. Reagents to analyze glucose, triglyceride, high-density lipoprotein (HDL), low-density lipoprotein (LDL), cholesterol, albumin, calcium, magnesium, and phosphorus were purchased from JW Medical (Seoul, Korea). The analytical reagents for non-esterified fatty acid (NEFA) were obtained from WAKO (Osaka, Japan). All of these items were analyzed using an automated chemistry analyzer (Hitachi 7180; Hitachi, Tokyo, Japan). Plasma cortisol was analyzed using a cortisol salivary HS enzyme-linked immunosorbent assay kit (cat. no. SLV4635; DRG Instruments, Marburg, Germany). All of the analysis methods were verified in our laboratory, as previously reported [17].

\section{Immune cell analysis}

The whole blood was used for analysis immune cell populations. Immune cell populations were measured as previously described
[17]. Briefly, a $100 \mu \mathrm{L}$ aliquot of whole blood was treated with $1 \mathrm{~mL}$ of Becton-Dickinson lysing buffer (Becton-Dickinson \& Company, Franklin lakes, NJ, USA), and total cell numbers were counted using a TC10 automated cell counter (Bio-Rad, Hercules, CA, USA). The granulocyte: lymphocyte ratio, identified by flow cytometry using the forward scatter and side scatter settings [18], was calculated as a percentage of total cells. Leukocytes $\left(5 \times 10^{5}\right.$ cells), stained with anti-bovine CD14-FITC and MHC class II DQ-PE antibodies for monocytes and B cells, respectively, and CD4-Alexa647 and CD8-PE (AbD Serotec, Raleigh, NC, USA) for T cells, respectively, for $15 \mathrm{~min}$ at $4^{\circ} \mathrm{C}$, were analyzed by flow cytometry (Becton-Dickinson, USA) and FlowJo software (TreeStar, Ashland, OR, USA). T cells were analyzed with $\mathrm{CD} 4$ or $\mathrm{CD} 8$ single positive among lymphocytes.

\section{Statistical analysis}

Climate data differences between months were analyzed using an one-way analysis of variance (ANOVA). Differences in growth performance and rectal temperatures, by dietary treatment and month, were analyzed using a two-way ANOVA. The repeated- 
measured two-way ANOVA and Tukey-Kramer test was used for blood parameters. The statistical model included diet, month, and their interaction. A p $<0.05$ was considered significant. All statistical tests were performed using R Studio for Windows software (R Studio, Boston, MA, USA).

\section{RESULTS AND DISCUSSION}

\section{Climate conditions and rectal temperature}

The mean (70.4) and maximum (75.8) indoor ambient THI in August (P1) was higher $(\mathrm{p}<0.001)$ than in September $(\mathrm{P} 2 ; 64.0$ and 69.7, respectively; Table 2). However, the maximum indoor temperature in August $\left(27.8^{\circ} \mathrm{C}\right)$ did not differ to that in September $\left(26.3^{\circ} \mathrm{C}\right)$. We also presented outdoor climate THI to show outside climate conditions of experimental barn. Indoor ambient THI values in both August and September were lower than outdoor climate THI values.

\section{Growth performance}

The daily concentrate diet intake was lower $(\mathrm{p}<0.001)$ in August compared to that in September (Table 3). In our study, the daily allowance of concentrate diet was set at $1.6 \%$ of $\mathrm{BW}$, and was adjusted each month based on BW. Thus, the higher concentrate intake simply reflects the increased concentrate allowance corresponding to a higher BW in September, compared to August. Daily forage intake did not differ between months. Glycerol addition did not affect concentrate diet or forage intake during all experimental periods. Glycerol addition did not affect concentrate/forage intake ratio and $\mathrm{CP}$ and crude fat $(\mathrm{EE})$ intake. The ratio in September was higher $(\mathrm{p}=0.014)$ than in August because amount of the concentrate diet supply in September was increased based on BW, whereas forage supply was fixed. The $\mathrm{CP}$ and crude fat intakes in September were higher $(\mathrm{p}<0.001)$
Table 2. Ambient temperatures, climate temperatures, relative humidity and temperature-humidity index ${ }^{11}$ in August and September, 2014

\begin{tabular}{|c|c|c|c|c|}
\hline Items & August $^{2)}$ & September ${ }^{3)}$ & SE & $p$-value \\
\hline \multicolumn{5}{|c|}{ Ambient temperature $\left({ }^{\circ} \mathrm{C}\right)$} \\
\hline Mean & 23.23 & 19.91 & 0.31 & $<0.001$ \\
\hline Maximum & 27.81 & 26.32 & 0.41 & 0.45 \\
\hline Minimum & 20.23 & 14.74 & 0.43 & $<0.001$ \\
\hline \multicolumn{5}{|c|}{ Climate temperature $\left({ }^{\circ} \mathrm{C}\right)$} \\
\hline Mean & 22.73 & 19.32 & 0.36 & $<0.001$ \\
\hline Maximum & 32.84 & 35.84 & 1.10 & 0.03 \\
\hline Minimum & 18.62 & 12.49 & 0.47 & $<0.001$ \\
\hline \multicolumn{5}{|c|}{ Ambient relative humidity (\%) } \\
\hline Mean & 81.96 & 75.61 & 0.95 & $<0.001$ \\
\hline Maximum & 91.94 & 59.21 & 0.40 & 0.19 \\
\hline Minimum & 65.98 & 32.22 & 2.07 & $<0.001$ \\
\hline \multicolumn{5}{|c|}{ Climate relative humidity (\%) } \\
\hline Mean & 74.58 & 71.35 & 1.64 & 0.78 \\
\hline Maximum & 90.49 & 87.48 & 1.42 & 0.014 \\
\hline Minimum & 55.02 & 25.45 & 2.89 & $<0.001$ \\
\hline \multicolumn{5}{|l|}{ Ambient THI } \\
\hline Mean & 70.36 & 64.00 & 0.51 & $<0.001$ \\
\hline Maximum & 75.77 & 69.65 & 0.51 & $<0.001$ \\
\hline Minimum & 66.32 & 56.67 & 0.66 & $<0.001$ \\
\hline \multicolumn{5}{|l|}{ Climate THI } \\
\hline Mean & 70.61 & 63.69 & 0.58 & $<0.001$ \\
\hline Maximum & 80.26 & 78.72 & 0.90 & 0.31 \\
\hline Minimum & 64.34 & 53.30 & 0.80 & $<0.001$ \\
\hline
\end{tabular}

$\mathrm{THI}$, temperature-humidity index; SE, standard error.

${ }^{1)} \mathrm{THI}=0.8 \times$ temperature $+[($ relative humidity $\times 0.01) \times($ temperature -14.4$)]+46.4$ (Gaughan et al [16]).

2) July 26 to August 26 (4 weeks). ${ }^{3)}$ August 27 to September 26 (4 weeks).

than in August because total DM intake was higher in September than in August.

Our primary purpose was to test whether glycerol addition instead of corn sources with iso-energy levels improves glucose

Table 3. Growth performance and rectal temperatures of Korean cattle steers fed either a control or glycerol-supplemented diet in August and September, 2014"

\begin{tabular}{|c|c|c|c|c|c|c|c|c|}
\hline \multirow{2}{*}{ Variable } & \multicolumn{2}{|c|}{ August $^{2)}$} & \multicolumn{2}{|c|}{ September $^{3)}$} & \multirow{2}{*}{ SE } & \multicolumn{3}{|c|}{ p-value } \\
\hline & Control & Glycerol & Control & Glycerol & & Diet & Month & Diet×month \\
\hline Age (month) & 14.4 & 14.0 & 15.4 & 15.0 & & & & \\
\hline Initial body weight (kg) & 405.0 & 405.2 & 434.7 & 430.7 & & & & \\
\hline Body weight ${ }^{4)}(\mathrm{kg})$ & 434.7 & 430.7 & 455.8 & 453.9 & 5.54 & 0.79 & 0.049 & 0.92 \\
\hline \multicolumn{9}{|l|}{ Feed intake, DM } \\
\hline Daily total feed intake (kg/d) & $7.63^{\mathrm{a}}$ & $7.62^{\mathrm{a}}$ & $8.21^{b}$ & $8.09^{\mathrm{ab}}$ & 0.08 & 0.68 & 0.0012 & 0.70 \\
\hline Daily concentrate intake (kg/d) & $5.44^{b}$ & $5.45^{b}$ & $6.00^{\mathrm{a}}$ & $5.93^{\mathrm{ab}}$ & 0.08 & 0.81 & $<0.001$ & 0.77 \\
\hline Daily forage intake $(\mathrm{kg} / \mathrm{d})$ & 2.19 & 2.18 & 2.20 & 2.16 & 0.03 & 0.61 & 0.93 & 0.81 \\
\hline Concentrate/forage intake ratio & $2.48^{\mathrm{a}}$ & $2.50^{\mathrm{a}}$ & $2.73^{b}$ & $2.75^{b}$ & 0.05 & 0.82 & 0.014 & 0.96 \\
\hline Crude protein intake $(\mathrm{kg} / \mathrm{d})$ & $0.86^{\mathrm{a}}$ & $0.88^{\mathrm{a}}$ & $0.92^{b}$ & $0.95^{b}$ & 0.014 & 0.47 & $<0.001$ & 0.77 \\
\hline Ether extract fat intake (kg/d) & $0.22^{\mathrm{a}}$ & $0.22^{\mathrm{a}}$ & $0.24^{b}$ & $0.24^{b}$ & 0.003 & 0.42 & $<0.001$ & 0.71 \\
\hline Average daily gain $(\mathrm{kg} / \mathrm{d})$ & $0.96^{\mathrm{a}}$ & $0.82^{\mathrm{ab}}$ & $0.70^{b}$ & $0.77^{\mathrm{ab}}$ & 0.04 & 0.62 & 0.03 & 0.13 \\
\hline Feed efficiency (gain/total DM feed intake) & $0.108^{\mathrm{a}}$ & $0.094^{\mathrm{ab}}$ & $0.075^{b}$ & $0.083^{\mathrm{ab}}$ & 0.0005 & 0.63 & 0.003 & 0.11 \\
\hline Rectal temperature $\left({ }^{\circ} \mathrm{C}\right)$ & 38.51 & 38.64 & 38.34 & 38.34 & 0.041 & 0.31 & 0.007 & 0.52 \\
\hline
\end{tabular}

SE, standard error; DM, dry matter.

1) $N=10$. Mean values with different letters $(a, b)$ differ at $p<0.05 .{ }^{2)}$ Experiment period was 4 weeks in duration (July 28 to August 26,2014 ).

3) Experiment period was 4 weeks in duration (August 27 to September 25, 2014). ${ }^{4)}$ Body weight was recorded on August 27 and September 26,2014 , respectively. 
metabolism under hot temperature, thereby improving growth performance. As described in below, glycerol addition did not change blood glucose concentrations. Glycerol addition did not also affect average daily gain (ADG) or feed efficiency (Table 3). One of reason for no effects of glycerol addition on glucose metabolism and growth performance is probably that Korean cattle was not affected by HS during August because growth performance during August at higher THI was better than September. Another possible reason for no improvement of growth performance is that glycerol diet contained iso-energy levels as control diet. Previously, supplementing of a 50:50 mixture of molasses:crude glycerol increased ADG in Angus crossbred heifers consuming Bermuda grass hay, although it did not affect feed efficiency [19].

The ADG and feed efficiency were higher $(\mathrm{p} \leq 0.03)$ in August compared to those in September. There was no interaction of diet $\mathrm{x}$ month for feed intake and ADG. Our results were not consistent with previous studies, which have shown decreases in ADG and feed efficiency at high THI conditions [3]. It is probable that, in our study, the average maximum THI in August and September was within the mild HS range and threshold range, respectively, according to the THI categories reported by [20] for lactating dairy cows. Therefore, Korean cattle may not suffer from HS within this THI range, probably more tolerant for HS than Holstein dairy cattle. The THI HS range of Korean cattle and other beef cattle has not yet been established. Other variables, such as genetic factors, diet and age, may affect the growth performance of cattle [21]. In our study, there was a 1-month difference in cattle age between August and September; however, it appeared that this difference did not significantly affect ADG and feed efficiency.

The rectal temperature of steers was higher $(\mathrm{p}<0.01)$ in August than in September, but glycerol addition did not affect rectal temperature (Table 3). Rectal temperature is a typical index of deep body temperature. A higher rectal temperature is associated with higher metabolic heat production in cattle [22].

\section{Blood cortisol and metabolites}

Blood was collected on July 28th, August 11th, 27th, and September 26 th, and the respective THI was $79.9^{\circ} \mathrm{C}, 72.2^{\circ} \mathrm{C}, 72.6^{\circ} \mathrm{C}$, and $65.3^{\circ} \mathrm{C}$, which was within "moderate HS", "mild HS", and below "threshold" ranges, respectively. Neither month nor diet affected blood cortisol concentrations (Figure 1). Consistent with our results, Johnson et al [23] reported that temperature did not affect blood cortisol concentrations. However, HS was accompanied by an increase in blood cortisol concentration in another study [24].

Blood triglyceride and NEFA concentrations did not differ between months, and were unaffected by glycerol addition (Figure 1). Previous studies have also demonstrated no changes in ruminant plasma NEFA concentrations by climate conditions $[25,26]$. Blood glucose concentrations were not affected by glycerol addition (Figure 1). Glycerol is mainly fermented to volatile fatty acids by rumen microbes, absorbed, and entered in the glucogenic pathway [27]. Therefore, our glycerol addition levels seemed to be not enough for increasing blood glucose concentrations in glycerol group. Blood glucose concentrations were lower on July 27th than on August 27th and September 26th (Figure 1). Our results were consistent with previous studies, which showed lower plasma glucose levels during a high-temperature period $[25,28]$. Decreased blood glucose under hotter conditions can be explained by several factors, including increased cost of thermoregulation, the negative effect of heat on gluconeogenesis, and endocrine acclimation [28]. Hassan and Roussel [29] reported that an increased respiration rate under high THI conditions can cause rapid utilization of blood glucose by respiratory muscles, thereby resulting in decreased blood glucose. Febbraio [30] reported that hepatic glucose output was elevated, but with decreased blood glucose levels in hot conditions, and suggested that glucose becomes a primary energy source for heat-stressed animals.

Blood cholesterol, LDL and HDL concentrations were higher on August 27th and September 26th, compared to those on July 28th, but were not affected by glycerol addition (Figure 1). Maximum THI on September 26th and July 28th was 65.3 and 79.9, respectively. Our study revealed that cholesterol, LDL and HDL concentrations were lower under high THI conditions. Ronchi et al [25] reported that lower blood cholesterol results from increased lipid utilization by peripheral tissues. In a chicken experiment, heat exposure was shown to decrease lipoprotein [31]. In addition, Faylon et al [32] suggested that HS has a direct effect on the regulation of lipolysis. Collectively, our results suggest that ambient THI may affect lipoprotein metabolism.

Blood albumin concentrations were higher on September 26th and August 27th than on July 28th, but these were not affected by glycerol addition (Figure 1). Perk and Lobl [33] reported that the albumin fraction of plasma is responsible for most of the effective osmotic pressure. At high THI conditions, cattle exhibited increased sweating and a high respiratory rate [34]. In this situation, cattle lose more water, as well as anions contained in sweat, through panting and sweating [9]; furthermore, heatinduced dehydration causes an imbalance in plasma osmolality [8]. Thus, in our study, low albumin concentrations at the highest THI condition may be a consequence of physiological activity aimed at maintaining blood osmolality.

Blood phosphorus, calcium and magnesium concentrations were higher on September 26th and August 27th than on July 28th, but these were not affected by glycerol addition, except for the phosphorus concentration on September 26th, which was higher in the glycerol group compared to the control group (Figure 2). Lower blood magnesium levels under higher THI conditions may result from increased utilization of $\mathrm{Mg}$ for lipolytic enzymes and a decrease in Mg transport through the rumen [35]. Previously, phosphorus and calcium levels were shown 

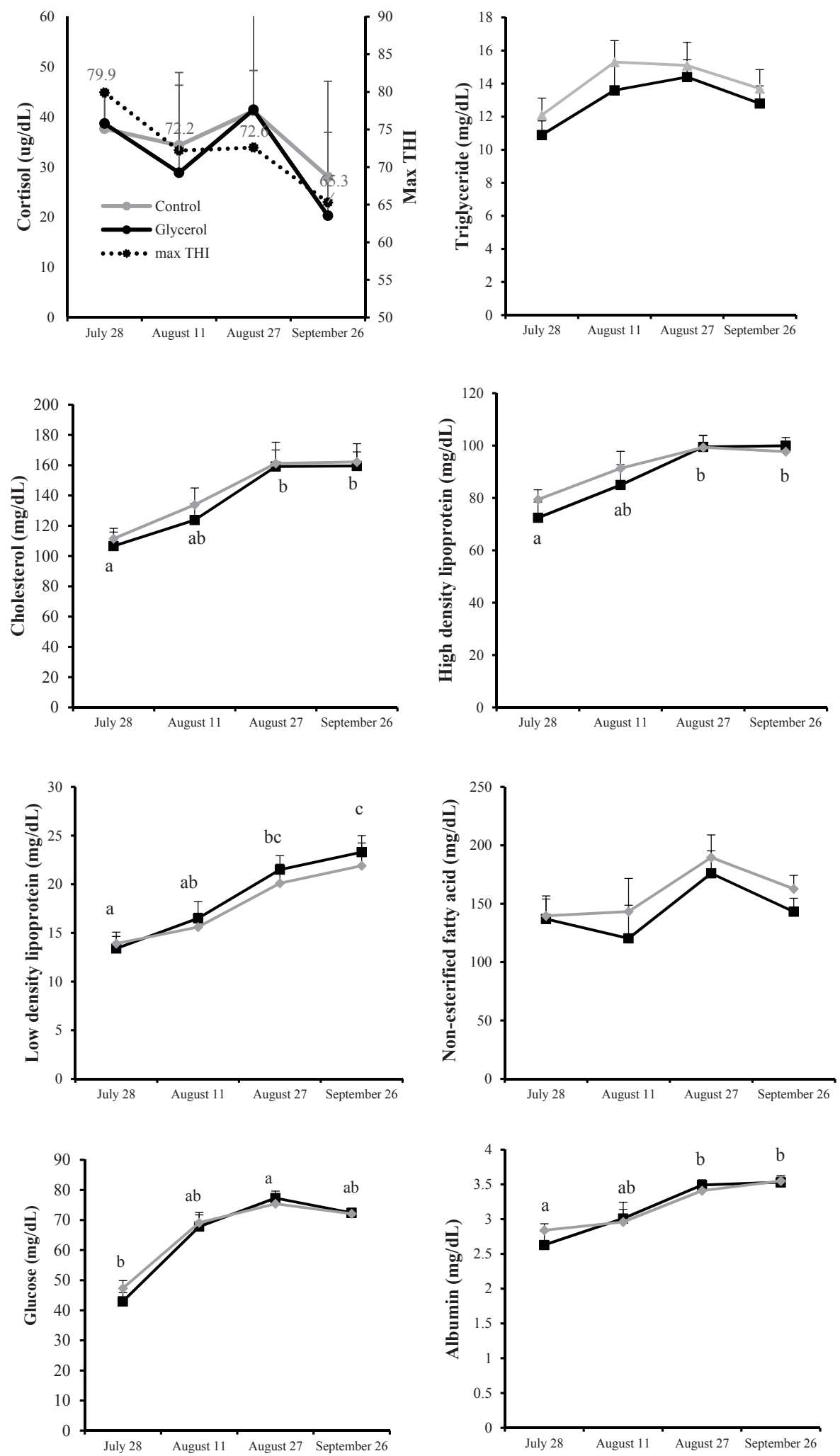

Figure 1. Plasma concentration of cortisol and serum concentrations of metabolites and maximum temperature humidity index (max THI) in Korean cattle steers for several different months. Values are means+standard error of the mean. Mean values with different letters $(a, b, c)$ differ $(p<0.05)$ by time within the same diet group. There was no interaction of dietxmonth for all parameters.

to decrease at high ambient temperatures [36]. Therefore, lower phosphorus and calcium levels under high THI conditions may be caused by a decrease in the retention ability of phosphorus and calcium, to maintain blood mineral balance in response 

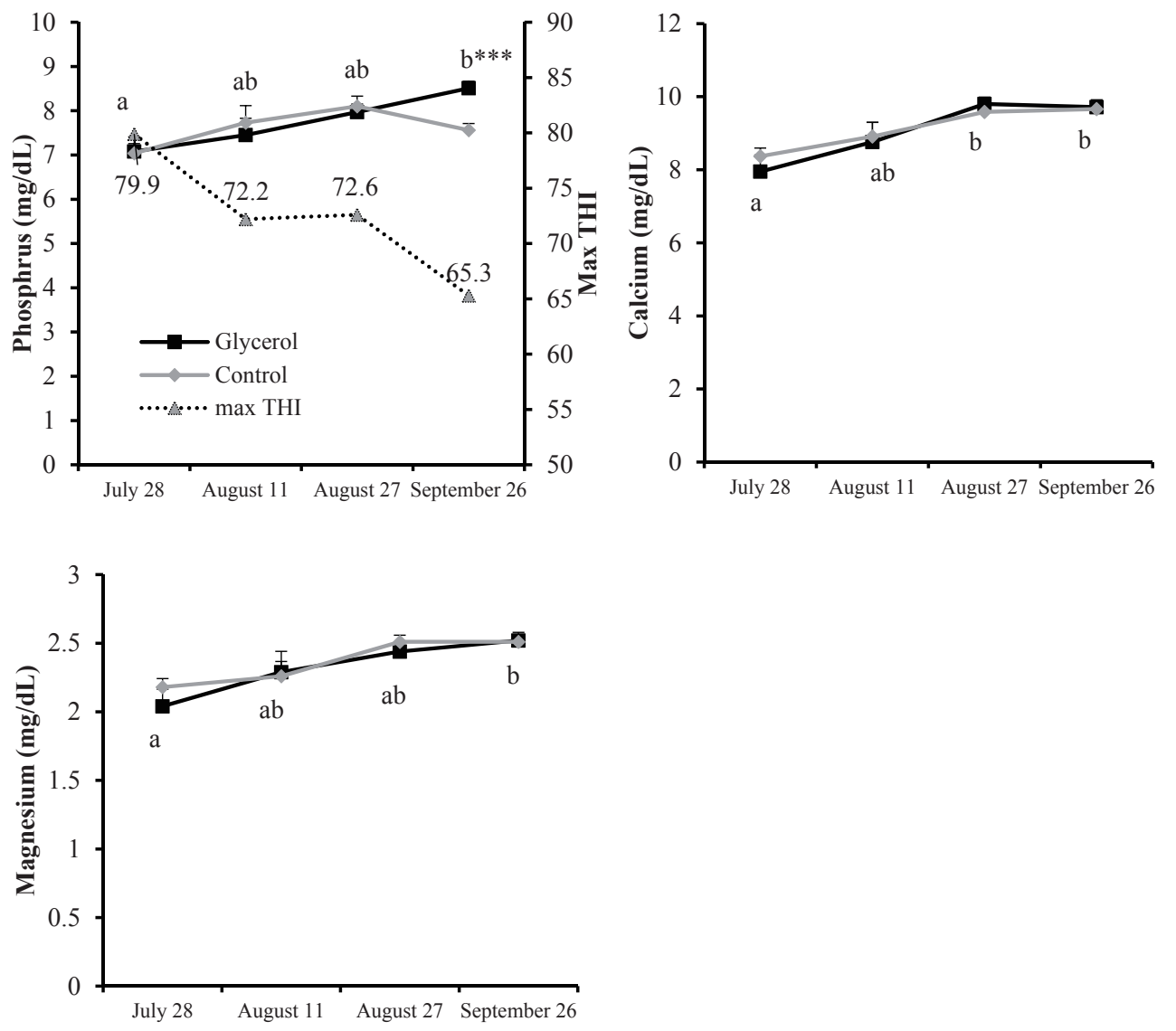

Figure 2. Serum concentrations of minerals in Korean cattle steers for several different months. Values are means+standard error of the mean. Mean values with different letters (a,b) differ $(p<0.05)$ by time within the same diet group. ${ }^{* *}$ Difference $(p<0.001)$ between the control and glycerol groups. There was no interaction of diet $\times$ month for all parameters.

to a loss of potassium due to increased sweating.

\section{Immune cells}

The granulocyte to lymphocyte blood ratio did not differ between months, and was unaffected by glycerol addition (Figure 3). The heterophil granulocyte to lymphocyte ratio has been previously used as an indicator of stress [37], and McFarlane and Curtis [38] reported that the heterophil granulocyte to lymphocyte ratio in chickens was raised during HS conditions. Hyperthermia and the consequent increase in cortisol secretion can suppress cell-mediated immunity by influencing the T-helper (Th) $1 / \mathrm{Th} 2$ ratio, with downregulation of Th1 cytokines in favor of Th2 cytokine secretion [39]. In our study, blood cortisol levels were unchanged. Therefore, an unaltered granulocyte to lymphocyte ratio may reflect a lack of blood cortisol differences related to climate conditions.

Percentages of $\mathrm{CD}^{+} \mathrm{T}$ cells and $\mathrm{CD} 8^{+} \mathrm{T}$ cells were higher $(\mathrm{p}<0.05)$ on July 28th than on August 27th and September 26th (Figure 3). Glycerol addition decreased blood $\mathrm{CD}^{+} \mathrm{T}$ cell population during late July and mid-August. However, it did not affect other blood immune cell populations. Currently, no information is available regarding the effects of HS and/or glycerol addition on $\mathrm{CD} 4^{+}$and $\mathrm{CD} 8^{+} \mathrm{T}$ cell populations. Further research is required to understand changes in $\mathrm{T}$ cell populations by HS in beef cattle.

\section{CONCLUSION}

The maximum indoor ambient THI in August (75.8) was higher than that in September (70.0), and the maximum August THI was within the mild HS category range reported for dairy cattle. Growth performance was not associated with climate conditions, since the ADG and feed efficiency were higher in August than in September, and blood cortisol concentrations did not change between months. Blood cholesterol, LDL, HDL, glucose, albumin, phosphorus, calcium and magnesium concentrations were lower during the hot conditions of August 27th conditions than in September. Glycerol addition did not affect the growth performance or blood concentrations of these parameters. Mild HS conditions, which have been demonstrated in dairy cattle, may not significantly affect the growth performance of Korean cattle, although some changes in blood metabolic and mineral parameters were detected during hotter months. Further research is warranted to identify HS conditions for reducing growth performance and feed efficiency in Korean cattle. 

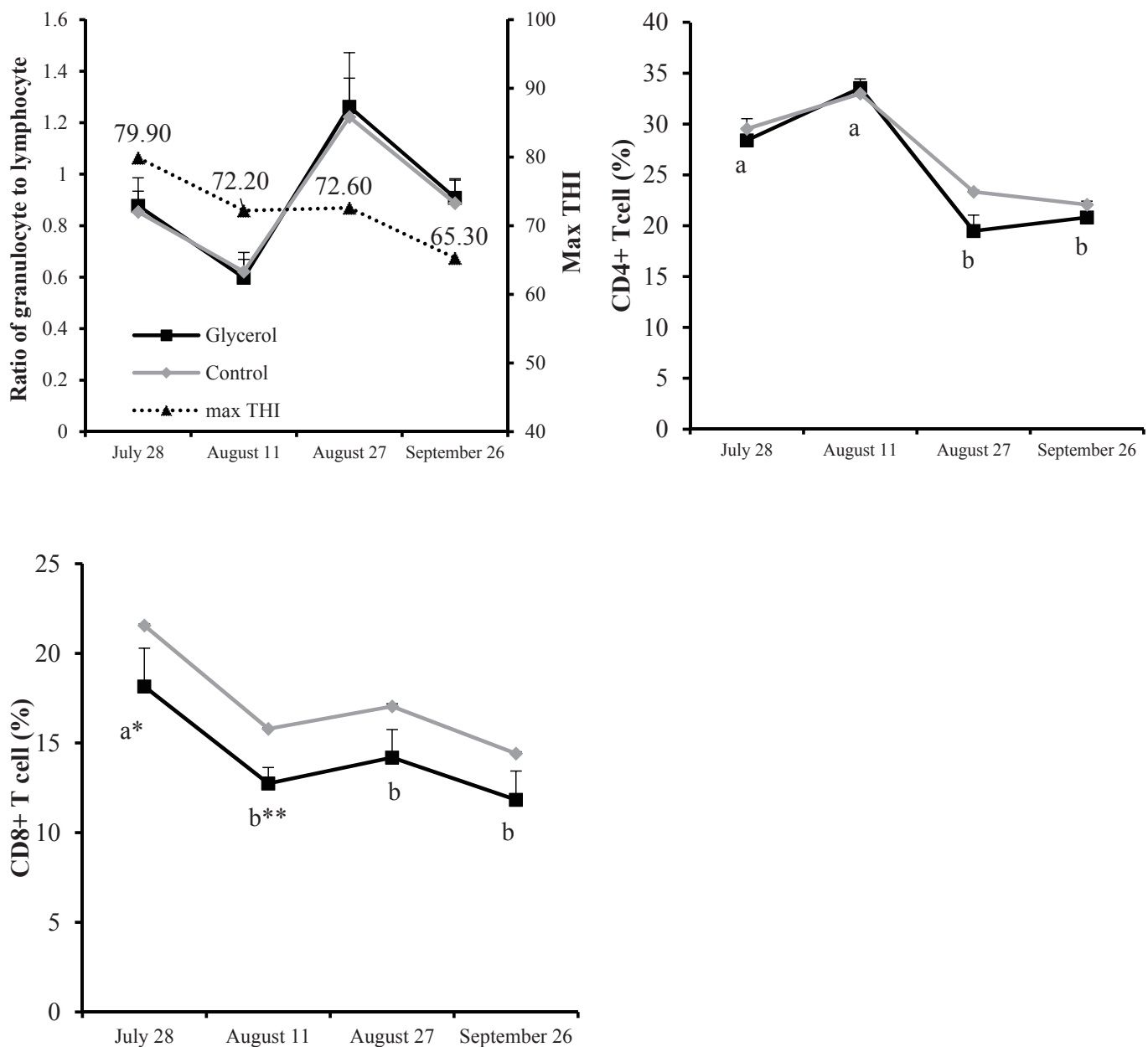

Figure 3. Whole blood ratio of granulocyte to lymphocyte and T cell populations in Korean cattle steers for several different months. Values are means+standard error of the mean Mean values with different letters $(a, b)$ differ $(p<0.05)$ by time within the same diet group. * Difference between the control and glycerol groups at $p<0.05$; ${ }^{* *}$ Difference between the control and glycerol groups at $p<0.01$. There was no interaction of diet $\times$ month for all parameters.

\section{CONFLICT OF INTEREST}

We certify that there is no conflict of interest with any financial organization regarding the material discussed in the manuscript.

\section{ACKNOWLEDGMENTS}

This study was supported by Korea Institute of Planning, and Evaluation for Technology in Food, Agriculture, Forestry and Fisheries (IPET) through Agri-Bio industry Technology Development Program, funded by Ministry of Agriculture, Food, and Rural Affairs (MAFRA) (313020-04-4-HD030), Republic of Korea, and by the Next Generation BioGreen 21 Program (No. PJ01114001), Rural Development Administration, Republic of Korea.

\section{REFERENCES}

1.Houghton JT, Ding Y, Griggs DJ, Noguer M. Intergovernmental Panel on Climate Change (IPCC). Climate Change 2001: The Scientific Basis, Contribution of Working Group to the Third Assessment Report of the Intergovernmental Panel on Climate Change. New York: Cambridge University Press; 2001.

2.Ho CH, Lee EJ, Lee I, Jeong SJ. Earlier spring in Seoul, Korea. Int J Climatol 2006;26:2117-27.

3.Hahn GL. Environmental influences on feed intake and performance of feedlot cattle. In: Proc. Symp. Intake by Feedlot Cattle. Owens FN, editor. Stillwater OK: Oklahoma State University; 1995. p. 207-25.

4.Yadav B, Pandey V, Yadav S, et al. Effect of misting and wallowing cooling systems on milk yield, blood and physiological variables during heat stress in lactating Murrah buffalo. J Anim Sci Technol 2016;58:2.

5.Beede DK, Collier RJ. Potential nutritional strategies for intensively managed cattle during thermal stress. J Anim Sci 1986;62:543-54.

6.Alvarez MB, Johnson HD. Environmental heat exposure on cattle plasma catecholamine and glucocorticoids. J Dairy Sci 1973;56: 189-94.

7.Allen TE, Bligh J. A comparative study of the temporal patterns of 
cutaneous water vapor loss from some domesticated mammals with epithelial sweat glands. Comp Biochem Physiol 1969;31:347.

8.Cunningham JG, Klein BG. Endocrine glands and their function. Textbook of veterinary physiology (4. Ed.) St. Louis, MO: Saunders Elsevier; 2007. p. 428-64.

9.El-Nouty FD, Elbanna IM, Davis TP, Johnson HD. Aldosterone and $\mathrm{ADH}$ response to heat and dehydration in cattle. J Appl Physiol Respir Environ Exercise Physiol 1980;48:249-55.

10. Boyd J, Bernard JK, West JW. Effects of feeding different amounts of supplemental glycerol on ruminal environment and digestibility of lactating dairy cows. J Dairy Sci 2013;96:470-6.

11. Wang C, Liua Q, Yang WZ, et al. Effects of glycerol on lactation performance, energy balance and metabolites in early lactation Holstein dairy cows. Anim Feed Sci Technol 2009;151:12-20.

12. Lomander H, Frössling J, Ingvartsen KL, Gustafsson H, Svensson C. Supplemental feeding with glycerol or propylene glycol of dairy cows in early lactation-Effects on metabolic status, body condition, and milk yield. J Dairy Sci 2012;95:2397-408.

13. Boyd J, West JW, Bernard JK. Effects of the addition of direct-fed microbials and glycerol to the diet of lactating dairy cows on milk yield and apparent efficiency of yield. J Dairy Sci 2011;94:4616-22.

14. AOAC. Official Methods of Analysis. 15th ed., Association of Official Analytical Chemists. Washington, DC: AOAC International; 1996. p. 210-9.

15. Thom EC. The discomfort index. Weatherwise 1959;12:57-9.

16. Gaughan JB, Bonner SL, Loxton I, Mader TL. Effects of chronic heat stress on plasma concentration of secreted heat shock protein 70 in growing feedlot cattle. J Anim Sci 2013;91:120-9.

17. Kang HJ, Lee IK, Piao MY, et al. Effects of ambient temperature on growth performance, blood metabolites, and immune cell populations in Korean cattle steers. Asian-Australas J Anim Sci 2016;29:436-43.

18. Kampen AH, Tollersrud T, Lund A. Flow cytometric measurement of neutrophil respiratory burst in whole bovine blood using live Staphylococcus aureus. J Immunol Methods 2004;289:47-55.

19. Ciriaco FM, Henry DD, Mercadante VR, et al. Effects of different levels of supplementation of a 50:50 mixture of molasses:crude glycerol on performance, Bermuda grass hay intake, and nutrient digestibility of beef cattle. J Anim Sci 2015;93:2428-38.

20. Collier RJ, Hall LW, Rungruang S, Zimbleman RB. Quantifying heat stress and its impact on metabolism and performance. In: Proceedings of the Florida Ruminant Nutrition Symposium 2012; 2012 Jan 31 - Feb 1, Gainesville, FL. p. 74-83.

21. Goonewardene LA, Beng RT, Hardin RT. A growth study of beef cattle. Can J Anim Sci 1981;61:1041-8.

22. Srikandakumar A, Johnson EH. Effect of heat stress on milk production, rectal temperature, respiratory rate and blood chemistry in Holstein, Jersey and Australian milking Zebu cows. Trop Anim Health Prod 2004;36:685-92.

23. Johnson HD, Li R, Manalu W, et al. Effects of somatotropin on milk yield and physiological responses during summer farm and hot laboratory conditions. J Dairy Sci 1991;74:1250-62.

24. Wise ME, Armstrong DV, Huber JT, Hunter R, Wiersma F. Hormonal alterations in the lactating dairy cow in response to thermal stress. J Dairy Sci 1988;71:2480-5.

25. Ronchi B, Bernabucci U, Lacetera N, Verini Supplizi A, Nardone A. Distinct and common effects of heat stress and restricted feeding on metabolic status of Holstein heifers. Zoot Nutr Anim 1999;25:11-20.

26. Rhoads ML, Rhoads RP, VanBaale MJ, et al. Effects of heat stress and plane of nutrition on lactating Holstein cows: I. production, metabolism and aspects of circulating somatotropin. J Dairy Sci 2009;92:1986-97.

27. Remond B, Souday R, Jouany JP. In vitro and in fermentation of glycerol by rumen microbes. Anim Feed Sci Technol 1993;41: 121-32.

28. Abeni F, Calamari L, Stefanini L. Metabolic conditions of lactating Friesian cows during the hot season in the Po valley. 1 . Blood indicators of heat stress. Int J Biometeorol 2007;52:87-96.

29. Hassan A, Roussel JD. Effect of protein concentration in the diet on blood composition and productivity of lactating Holstein cows under thermal stress. J Agric Sci Camb 1975;85:409-15.

30. Febbraio MA. Alterations in energy metabolism during exercise and heat stress. Sports Med 2001;31:47-59.

31. Gould NR, Siegel HS. Serum lipoproteins in chickens after administration of adrenocorticotropin or exposure to high temperature. Poult Sci 1985;64:567-74.

32. Faylon MP, Baumgard LH, Rhoads RP, Spurlock DM. Effects of acute heat stress on lipid metabolism of bovine primary adipocytes. 2015; 98:8732-40.

33. Perk K, Lobl K. A comparative study on the sera proteins and lipids in two breeds of cattle. Br Vet J 1959;115:411-5.

34. Finch VA. Body temperature in beef cattle: Its control and relevance to production in the tropics. J Anim Sci 1986;62:531-42.

35. Calamari L, Abeni F, Calegari F, Stefanini L. Metabolic conditions of lactating Friesian cows during the hot season in the Po valley. 2. Blood minerals and acid-base chemistry. Int J Biometeorol 2007; 52:97-107.

36. Kume S, Kurihara M, Takahashi S, Shibata M, Aii T. Effect of hot environmental temperature on major mineral balance in dry cows. Jpn J Zootech Sci 1986;57:940-5.

37. Gross WB, Siegel HS. Evaluation of the heterophil/lymphocyte ratio as a measure of stress in chickens. Avian Dis 1983;27:972-9.

38. McFarlane JM, Curtis SE. Multiple concurrent stressors in chicks. 3. Effects on plasma corticosterone and the heterophil:lymphocyte ratio. Poult Sci 1989;68:522-7.

39. Elenkov IJ, Chrousos GP. Stress hormones, Th1/Th2 patterns, pro/ anti-inflammatory cytokines and susceptibility to disease. Trends Endocrinol Metab 1999;10:359-68.

40. NRC. Nutrient requirements of dairy cattle. 7th rev. ed. Washington, DC: National Academy Press, 2001. 